UCRL-ID-119832

\title{
Corrosion of Candidate Materials in Lake Rotokawa Geothermal Exposure
}

John C. Estill

R. D. McCright

May 1995

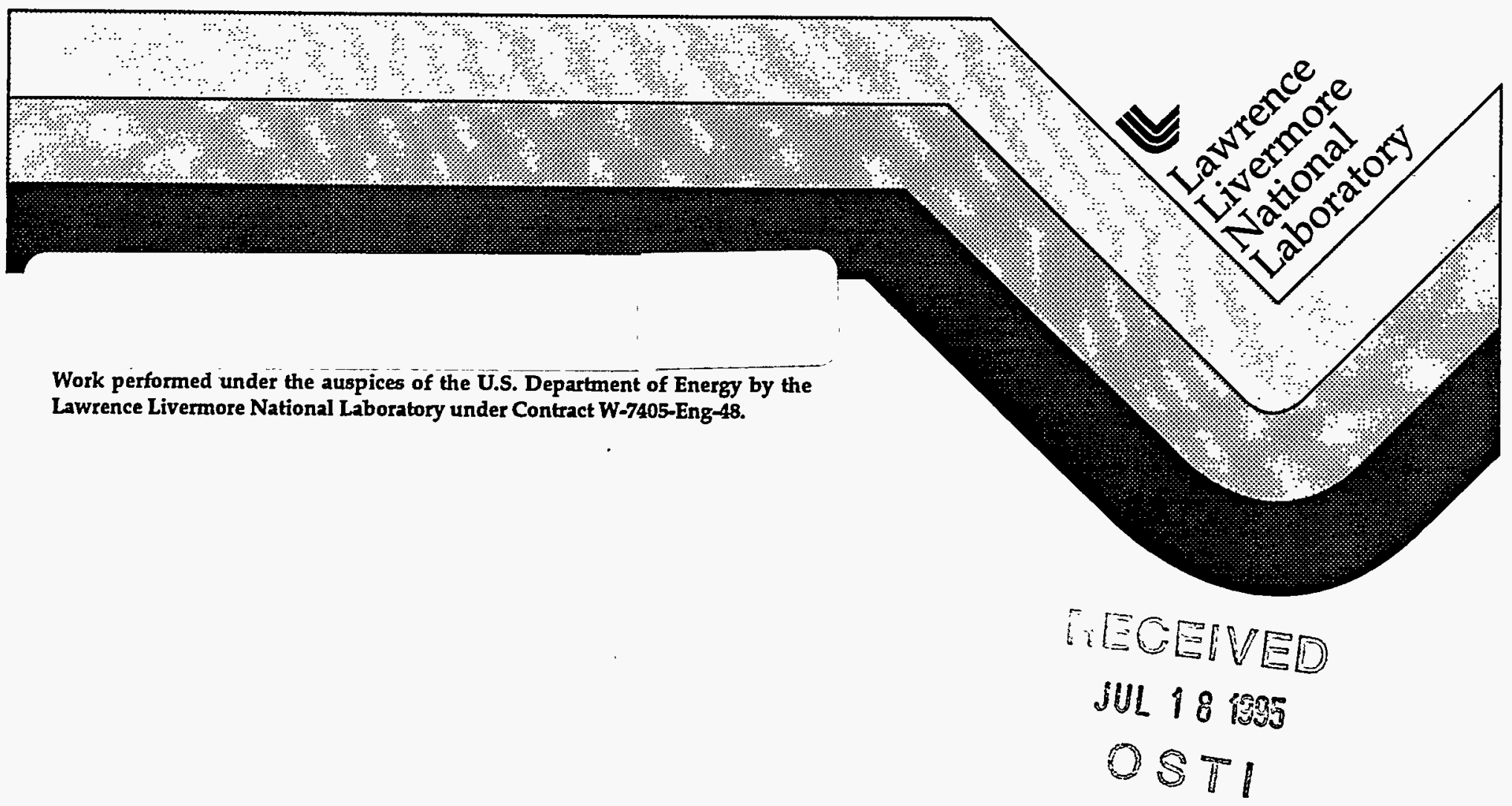




\section{DISCLAIMER}

This document was prepared as an account of work sponsored by an agency of the United States Government. Neither the United States Government nor the University of California nor any of their employees, makes any warranty, express or implied, or assumes any legal liability or responsibility for the accuracy, completeness, or usefulness of any information, apparatus, product, or process disclosed, or represents that its use would not infringe privately owned rights. Reference herein to any specific commercial product, process, or service by trade name, trademark, manufacturer, or otherwise, does not necessarily constitute or imply its endorsement, recommendation, or favoring by the United States Government or the University of California. The views and opinions of authors expressed herein do not necessarily state or reflect those of the United States Government or the University of California, and shall not be used for advertising or product endorsement purposes.

This report has been reproduced directly from the best available copy.

Available to DOE and DOE contractors from the Office of Scientific and Technical Information P.O. Box 62, Oak Ridge, TN 37831

Prices available from (615) 576-8401, FTS 626-8401

Available to the public from the National Technical Information Service

U.S. Department of Commerce 5285 Port Royal Rd.

Springfield, VA 22161

Prepared by Yucca Mountain Site Characterization Project (MMP) participants as part of the Civilian Radioactive Waste Management Program. The YMP is managed by the Yucca

Mountain Site Characterization Project Office of the U.S. Department of Energy, Las Vegas, Nevada. 


\section{DISCLAIMER}

Portions of this document may be illegible in electronic image products. Images are produced from the best available original document. 


\title{
Corrosion of Candidate Materials in Lake Rotokawa Geothermal Exposure
}

\author{
John C. Estill
}

R.D. McCright

\begin{abstract}
Corrosion rates were determined for CDA 613, CDA 715, A-36 carbon steel, 1020 carbon steel, and Alloy 825 flat coupons which were exposed to geothermal spring water at Paraiki site number 9 near Lake Rotokawa, New Zealand. Qualitative observations of the corrosion performance of Type 304L stainless steel and CDA 102 exposed to the same environment were noted.

CDA 715, Alloy 825, 1020 carbon steel, and other alloys are being considered for the materials of construction for high-level radioactive waste containers for the United States civilian radioactive waste disposal program. Alloys CDA 613 and CDA 102 were tested to provide copper-based materials for corrosion performance comparison purposes. A36 was tested to provide a carbon steel baseline material for comparison purposes, and alloy $304 \mathrm{~L}$ stainless steel was tested to provide an austenitic stainless steel baseline material for comparison purposes.
\end{abstract}

In an effort to gather corrosion data from an environment that is rooted in natural sources of water and rock, samples of some of the proposed container materials were exposed to a geothermal spring environment. At the proposed site at Yucca Mountain, Nevada, currently under consideration for high-level nuclear waste disposal, transient groundwater may come in contact with waste containers over the course of a 10,000-year disposal period. The geothermal springs environment, while extremely more aggressive than the anticipated general environment at Yucca Mountain, Nevada, could have similarities to the environment that arises at selected local sites on a container as a result of crevice corrosion, pitting corrosion, microbiologically influenced corrosion (MIC), or the concentration of the ionic species due to repetitive evaporation or boiling of the groundwater near the containers.

The corrosion rates were based on weight loss data obtained after six weeks exposure in a $90^{\circ} \mathrm{C}$, low-pH spring with relatively high concentrations of $\mathrm{SO}_{4}{ }^{2-}$ and $\mathrm{Cl}^{\circ}$. 


\section{Introduction}

Three alloys being considered for high-level radioactive waste containment were part of a broader group of alloys exposed to a geothermal spring environment at Lake Rotokawa, New Zealand to evaluate their relative corrosion resistance. The geothermal field, located at Paraiki Site Number 9, provides a naturally produced aggressive environment of high temperature, low $\mathrm{pH}$, and corrosive ionic species. ${ }^{1}$ The environment in the hot springs is of particular interest because of its similarities with conditions which may present themselves at local corrosion sites on the waste containers during the 10,000-year controlled-release period of waste disposal. The hot spring has a temperature near $90^{\circ} \mathrm{C}$, acidic conditions ( $\mathrm{pH} 2$ ), and high concentrations of $\mathrm{SO}_{4}{ }^{2-}$ and $\mathrm{Cl}^{-}$ions, as well as silica and other inorganics.

The site under consideration for the potential United States civilian high-level radioactive waste repository is located at Yucca Mountain, Nevada. As a result of the radioactive decay of materials that would be contained within the waste containers at Yucca Mountain, the temperature of the near-field environment surrounding the containers might be as high as $250^{\circ} \mathrm{C}$ initially and decline to $90^{\circ} \mathrm{C}$ or less as the thermal output in the near-field decreased. Naturally or thermally driven vadose groundwater flows may enter the elevated-temperature, near-field environment and produce highhumidity conditions. Thus, the container could be exposed to corrosive conditions as a result of the vadose water interaction with the container. Concentration of ionic species in the bulk water, including $\mathrm{SO}_{4}{ }^{2-}$ and $\mathrm{Cl}^{-}$, could rise to the saturation point due to repetitive evaporation effects or reflux of water in the near field. Yucca Mountain groundwater 
contains only small amounts of $\mathrm{SO}_{4}{ }^{2-}$ and $\mathrm{Cl}^{-}$in the bulk environment. ${ }^{2}$ However, hydrological and geochemical processes over thousands of years could bring about large increases in the concentration of these anions near the containers. Low-pH conditions are not uncommon locally as a result of differential oxygen concentrations such as would occur at favorable crevice sites on the waste containers. ${ }^{3}$ The resulting oxygen concentration cell in a crevice could drive down the $\mathrm{pH}$ and create a much more aggressive local environment. Low-pH conditions might also be present as a result of MIC. Microbial metabolic products tend to produce low-pH chemistry; an example is hydrogen sulfide, produced by sulfate reducing bacteria. ${ }^{4}$

Alloy $825, \mathrm{CDA} 715$, and 1020 carbon steel are three of the alloys on the current list of candidate materials for high-level radioactive waste containment. ${ }^{5}$ One of the container designs envisions a relatively thick carbon steel outer container and a reduced thickness corrosion-resistant inner container. Another proposed design incorporates an equally thick copper-nickel alloy outer container and a corrosion-resistant alloy inner container. Alloy 825 is one of the candidate corrosion-resistant materials, CDA 715 one of the copper-nickel materials, and 1020 steel is a carbon steel material. CDA 102 copper, A36 carbon steel, and 304L stainless steel were tested for comparison purposes.

The Paraiki site, with elevated levels of $\mathrm{SO}_{4}{ }^{2-}$ and $\mathrm{Cl}^{-}$, low-pH chemistry, and 90 ${ }^{\circ} \mathrm{C}$ temperature presents a very aggressive environment that one might expect to be repository-relevant only on a reduced scale, i.e., at crevice sites and MIC sites where the rock and waste container interact. Although the bulk environment at Yucca Mountain is significantly more benign than that of Paraiki Site Number 9 spring water, the geothermal spring water may serve as a worst case environment of crevice, pitting, or MIC sites on a 
container. Therefore, the corrosion rates are not indicative of the rates that may result by emplacing coupons in the Yucca Mountain site, but rather, are simply a gauge for judging the relative corrosion resistance of alloys in an extremely aggressive naturally evolved environment; an environment that may be relevant only to local corrosion sites on a container and not on the greater part of the container. The observed corrosion rates and the physical examination of the coupons are summarized in this report.

Data from this exposure will aid in the material selection decision for nuclear waste containers by supplementing the data derived from the program of long-term testing of candidate materials currently underway at Lawrence Livermore National Laboratory (LLNL).

\section{Materials}

Seven alloys were tested, including materials from the austenitic stainless steels, carbon steels, copper-based, and nickel-based austenitic systems. As already mentioned, three of the alloys, $\operatorname{CDA} 715$, Alloy 825, and 1020 carbon steel are included in the current candidate list for materials under consideration for high-level radioactive waste containment for the United States civilian radioactive waste program. The remaining five alloys are similar to other materials in the current candidate list. The alloys and their compositions are shown in Table 1. 
Table 1. Alloys Exposed to Geothermal Conditions

\begin{tabular}{|c|c|c|}
\hline Alloy & UNS Number & Nominal Composition \\
\hline A-36 Carbon Steel & K02600 & $\begin{array}{l}\text { C } 0.26 \max ; \mathrm{Mn} 0.80-1.20 \\
\text { P } 0.04 \max ; \text { S } 0.05 \max \end{array}$ \\
\hline 1020 Carbon Steel & G10200 & $\begin{array}{l}\text { C } 0.22 \text { max; Mn 0.6-1.20; } \\
\text { P 0.035 max; S 0.040 max; } \\
\text { Si 0.15-0.40; Fe remainder. }\end{array}$ \\
\hline CDA 613 (Copper-Based) & C61300 & $\begin{array}{l}\mathrm{Al} 6.0-7.5 ; \mathrm{Fe} 2.0-3.0 ; \mathrm{Mn} 0.2 \mathrm{max} \\
\mathrm{Ni} 0.15 \max ; \mathrm{P} .015 \max \\
\mathrm{Pb} 0.01 \mathrm{max} ; \mathrm{Si} 0.10 \mathrm{max} \\
\mathrm{Sn} 0.2-0.5 ; \mathrm{Zn} 0.10 \max \end{array}$ \\
\hline CDA 102 (Copper-Based) & $\mathrm{C} 10200$ & Oxygen Free $99.95 \mathrm{Cu} \min$;. \\
\hline CDA 715 (Copper-Based) & C71500 & $\begin{array}{l}\text { Ni 29.0-33.0; Cu balance; } \\
\text { Mn 1.0 max; Pb 0.02 max; } \\
\text { Fe 0.4-1.0; Zn 0.5 max; C } 0.05 \max \\
\text { P 0.02 max; S } 0.02 \text { max }\end{array}$ \\
\hline 304L Austenitic Stainless Steel & S30403 & 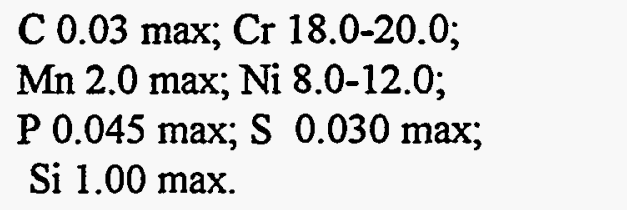 \\
\hline Alloy 825 (Nickel-Based) & N08825 & $\begin{array}{l}\text { Ni } 38.0-46.0 ; \text { Cr } 19.5-23.5 ; \\
\text { Mo } 2.5-3.5 ; \text { Fe balance; } \\
\text { Cu } 1.5-3.0 ; \mathrm{Ti} 0.6-1.2 ; \\
\text { Mn } 1.0 \max ; \mathrm{C} 0.05 \max \\
\text { Si } 0.5 \max ; \mathrm{S} 0.03 \max \\
\text { Al } 0.2 \max \text {. }\end{array}$ \\
\hline
\end{tabular}




\section{Experimental}

\section{Test Specimens}

Samples of U-bends (nominal thickness 1-mm) prepared according to the general requirements of ASTM G46 were used to evaluate stress corrosion resistance. ${ }^{6}$ A pair of $50-\mathrm{mm}$ by $50-\mathrm{mm}$ by $3-\mathrm{mm}$ panels, bolted together to form a crevice contact, were used in the evaluation of crevice corrosion resistance. $25-\mathrm{mm}$ by $50-\mathrm{mm}$ flat coupons (1.8-mm nominal thickness) were used to measure weight loss for use in the calculation of corrosion rates as well as characterization of general corrosion.

To minimize space occupied in the geothermal spring not all specimen types from each alloy were represented in the test matrix. Flat coupons of Alloys A36 and 1020 carbon steel, $\mathrm{CDA} 613, \mathrm{CDA} 715$, and 825 were exposed for weight loss determinations. U-bend samples from Alloys CDA 102, CDA 613, and 304L were evaluated for stress corrosion resistance, and a crevice assembly from Alloy CDA 613 was evaluated for crevice corrosion resistance.

The samples were tested in a surface-polished 120-grit condition to eliminate the effects of differences in mill finish of the various alloys. The samples were cleaned in isopropyl alcohol prior to shipment to the Lake Rotokawa area.

\section{Geothermal Environment}

The volume of the spring water at Paraiki Site Number 9 was approximately 400 liters, and the pool was about $0.6 \mathrm{~m}$ deep. The natural gas flow rate through the spring was relatively low and the release was described as a gentle bubbling process. ${ }^{7}$ The 
temperature of the spring was $89^{\circ} \mathrm{C}$, and the $\mathrm{pH}$ was 2.07 . Elemental concentrations in the spring water are given below:

Paraiki Site Number 9 Elemental Concentration $\mathrm{mg} / \mathrm{L}$

$\mathrm{Cl}$

$\mathrm{SO}_{4}$

$\mathrm{Br}$

$\mathrm{SiO}_{2}$

431

1130

1.26

324

Using a polyester string, the specimens were suspended vertically near the bottom of the spring and were exposed for six weeks. After the specimens were removed from the spring, they were dried, packaged in plastic bags, and returned to LLNL for analysis.

\section{Results and Discussion}

Upon arrival at LLNL the samples were visually examined before and after cleaning. Selected cross sections were obtained for metallographic examination. Weight loss determinations of the flat $25-\mathrm{mm}$ by $50-\mathrm{mm}$ specimens were made after chemical cleaning with appropriate agents.

\section{As-Received Examination}

A visual examination of each specimen was made after carefully removing the coupons from the plastic shipping bags. The results of this examination are presented in Table 2. All of the carbon steel and Type 304L stainless steel specimens had completely dissolved in the geothermal spring during the six-week exposure. The severe general corrosion attack on the remaining alloys produced large quantities of corrosion product and masked any attack due to crevice corrosion or stress corrosion cracking. The base 
metal surface was impossible to observe because of the excessive corrosion products present on all alloys. Therefore, the as-received examination was simply observation of the corrosion products.

Although the corrosion attack is severe on all samples, the morphology of the corrosion product is distinct between alloys. Surface features on the Alloy 825 specimens consisted of substantial amounts of large flakes of corrosion product that appeared to be the result of an exfoliated-mode attack. The corrosion product morphology suggests complete surface layer removal as general corrosion proceeds.

The CDA 613 and CDA 102 corrosion products had very fine consistencies, granular morphologies with uniform size distribution. Although the corrosion products of the CDA 613 and CDA 102 are similar, the extents of attack are markedly different. Since no weight-loss coupons were tested for alloy CDA 102, comparisons are based on qualitative observations of the alloys. The size of the CDA 102 U-bend sample, as a result of more severe general corrosion attack, is noticeably smaller than that of the CDA $613 \mathrm{U}-$ bend. Although weight loss data were not obtained for CDA 102, the comparative general corrosion attack of CDA 102 and CDA 613 U-bends suggests a higher corrosion rate for CDA 102. The CDA 715 corrosion product exhibits a mix between very fine granular and flaky morphology. The flaky corrosion product appears to be similar to the Alloy 825 corrosion product. Perhaps the thirty-percent nickel content in CDA 715 contributes to the similarity in corrosion product morphology with that of the nickel-rich Alloy 825 .

One interesting observation is the variation in the attack on the Type 316 stainless steel loading bolts used in the U-bend and crevice specimens. The bolt/nut assembly used for stressing the CDA 102 U-bend, isolated from the specimen with ceramic washers, was 
nearly pristine and did not suffer any corrosion damage. The isolated Type 316 stainless steel bolts used in loading the CDA 613 U-bend coupon, however, did suffer some minor corrosion attack. The attack was relatively cosmetic and the surfaces of the threads were intact with some staining and minor pitting. Interestingly, only one nut appeared to be corroded (the bolted assembly contains two nuts butted up against each other), while the other was pristine. The isolated bolt/nut assembly on the CDA 613 crevice coupon suffered more severe corrosion attack, and the bolts and nuts were corroded to the extent that the integrity of a tight crevice assembly was compromised. This anomaly of varying degrees of attack on Type 316 stainless steel loading bolts from one specimen to another may be explained if we examine corrosion product accumulation on a specimen. Perhaps the bolt/nuts were electrically coupled to the metal sample via the excessive corrosion product in contact with the specimen and the bolts. This may have caused galvanic coupling between the bolt and specimen, leading to varying results.

\section{Post-Cleaning Examination}

Following the as-received specimen examination, the specimens were cleaned in acidified solutions that are described in the requirements of ASTM G1. ${ }^{8}$ The acid cleaning procedures from one alloy to another differ only in the acid used. All samples were cleaned at room temperature for three minutes in the appropriate acidified solution, rinsed in distilled water while scrubbing with a nylon brush, and air dried. CDA 613 and CDA 715 specimens were cleaned in a 10-percent by volume concentrated sulfuric acid solution, and Alloy 825 specimens were cleaned in a 15-percent by volume concentrated 
hydrochloric acid solution. The visual examination of each specimen was performed after the prescribed cleaning, and results are presented in Table 3.

The corrosion attack on all three Alloy 825 flat weight-loss specimens was severe. The surfaces of two of the three specimens reveal a random pattern of variable depths of attack. The surfaces of these specimens are not flat, but instead appear very rough. These two specimens have discolored metal (brown and black) islands which are peppered about the surface and below which lies a shiny silver-colored base metal layer, which is relatively smooth in texture. The third specimen has a very shiny surface with a wavy morphology. The depth of attack varies on this specimen, and the surface appears to be filled with large blisters. The shiny color is not the same as is observed before testing. A gray color is typical of the surface prior to testing. Weight loss data indicate that the specimen with the shiny, wavy surface is the one that experienced the most severe attack. The dark-colored islands of metal described above may be systematically dissolved as corrosion attack proceeds, leaving a shiny surface behind as the islands of metal go into solution.

The CDA 613 samples suffered less corrosion attack than any of the other alloys. The surfaces of the U-bend, crevice, and weight-loss coupon are all very similar, appearing clean and smooth, with only mottled staining present. The U-bend sample was the most severely attacked, showing some minor pitting; however, the pitting was very shallow. No stress-corrosion cracking or crevice corrosion attack was observed. The corrosion attack was characterized as uniform, general corrosion attack with no significant surface defects resulting from the exposure. 
Two weight-loss specimens of Alloy CDA 715 suffered corrosion attack that is characterized in intensity as between the corrosion attack of Alloy CDA 613 and 825, but more closely paralleling the performance of Alloy 825. The surface of the CDA 715 looks like that of a specimen that experienced erosion-corrosion attack. However, discussions with staff at the Paraiki site, and their observation of a rather gentle bubbling of the spring water, would seem to discount this possibility. Nonetheless, the surface looks as though it melted, with flowing features about the surface, and is typical of the appearance of a specimen that has experienced erosion-corrosion attack. The depth of attack varies slightly across the specimen, the varying depth corresponding to the melted appearance of the surface. There are no islands of metal present as there were on Alloy 825; rather, there is just a uniform melted appearance about the samples. Both CDA 715 specimens have similar surface attack features and cannot be distinguished from one another.

\section{Optical Metallography}

\section{As-Polished}

Cross sections of Alloys CDA 613, CDA 715, and 825 are presented in Figures 1, 2 , and 3 , respectively. The samples are sectioned across the $25-\mathrm{mm}$ width of the flat weight-loss coupons. The cross section examinations are as-polished to a one-micron finish. For comparison purposes a witness specimen, that has not been tested, was placed in the same metallographic mount to provide a visual contrast of the extent of attack through the thickness. The cross sections suggest different depths of attack among these three alloys. 
The Alloy CDA 613 specimen shows the least amount of attack and is uniform in depth of corrosion attack throughout the cross section (see Figure 1). No localized attack is observed that penetrates preferentially into the depth of the specimen.

Alloy CDA 715 shows significant depth of attack considering the short exposure time; however, the attack is fairly uniform and rises and falls gently across the width of the specimens (Figure 2).

The Alloy 825 specimen ( 1 of 3 specimens tested) selected for sectioning had the most severe corrosion attack. Weight-loss data suggest the corrosion attack on this specimen was more than twice that on the other two Alloy 825 specimens. Therefore, this cross section is representative of the worst-case corrosion attack. The corrosion attack is extensive across the width of the specimen. Depth of attack varies across the width of the specimen and is approximately two-thirds to three-fourths the original thickness of the specimen. The depth of attack appears to rise and fall like standing waves (Figure 3). No localized attack was observed that penetrates preferentially into depth; however, general corrosion attack produces a significant range in depth of attack. Although the other two weight-loss coupons of this alloy were not cross sectioned, we could expect somewhat less depth of attack because of the substanitially reduced weight loss of these specimens (about one half the weight-loss of the first one).

\section{Etched Cross Sections}

Chemically etched cross sections of alloys CDA 613, CDA 715, and Alloy 825 are presented in Figures 4, 5, and 6, respectively. In order to understand the substantial differences in the morphology of the corrosion product among the three alloys, 
representative cross sections were chemically etched to reveal the grain structures. The cross sections are the same as those previously examined in the as-polished condition. The photographs were obtained from the cross sections of the tested samples.

The CDA 613 cross section was etched in a solution of 75-percent lactic acid and 25-percent concentrated nitric acid. The etchant revealed an equiaxed grain structure with extremely small grains (Figure 4). There are no apparent cold-work etch-pit lines present as was observed in some of the other alloys. The grain structure was homogeneous with no significant change in size of grains through the thickness of the specimen.

The CDA 715 cross section was etched in a solution containing forty two grams of copper chloride, ninety-eight $\mathrm{ml}$ of concentrated hydrochloric acid, and two $\mathrm{ml}$ of concentrated nitric acid. Nomarski Interference Contrast (NIC) was used to enhance the grain structure image (Figure 5). The etchant revealed an equiaxed grain structure; however, longitudinal roll lines suggest a cold-worked grain structure. In addition, the typical grain size present in the CDA 715 structure is significantly larger than that in the CDA 613.

The Alloy 825 cross section was etched in a solution containing 42 grams of copper chloride, $98 \mathrm{ml}$ of concentrated hydrochloric acid, and $2 \mathrm{ml}$ of concentrated nitric acid. NIC was used to enhance the grain structure image (Figure 6). The etchant revealed an equiaxed grain structure with some longitudinal cold-work lines present, probably as a result of rolling. The cold-work lines are not as apparent as those present in the CDA 715. The grain size is nearly the same as in the $\operatorname{CDA} 715$, but much larger than the grain size of the CDA 613. Overall, the Alloy 825 cross section is very similar to the CDA 715 cross section, having comparable grain size and longitudinal cold-work lines. 


\section{Corrosion Rate Calculations}

Weight loss of specimens from alloys Alloy 825, CDA 613, and CDA 715 were used to calculate corrosion rates using the relation given in ASTM G1,

$$
\frac{K \times W}{A \times T \times D}=\text { Corrosion Rate (mm/year) }
$$

where:

$\mathrm{K}=\mathrm{a}$ dimension dependent constant, $8.76 \times 10^{4}$,

$\mathrm{W}=$ mass loss in grams,

$\mathrm{A}=$ area in $\mathrm{mm}^{2}$,

$\mathrm{T}=$ exposure time in years

$\mathrm{D}=$ density in $\mathrm{g} / \mathrm{mm}^{3}$.

Samples of Alloys of 1020 and A-36 carbon steel were also exposed for weightloss determinations; however, the specimens dissolved in the hot spring environment. Therefore, the corrosion rates for the carbon steel samples are denoted as minimum corrosion rate values and for the sake of calculation assumed to be completely dissolved at precisely the time they are removed from the hot spring (six weeks). The carbon steel samples may very well have dissolved much sooner, but there is no way to verify this. The compilation of corrosion rates for the tested alloys is presented in Table 4 .

As expected, the carbon steel alloys of 1020 and A-36 steel showed the highest corrosion rates. As stated earlier, these are minimum values, because of the unknown time for complete dissolution of the samples. 
Three Alloy 825 specimens showed corrosion rates ranging from 1.33 to $4.56 \mathrm{~mm}$ per year. One of the specimens produced markedly higher weight loss than the other two specimens, which may suggest a more aggressive local environment in the hot spring. The overall performance of this material is rather poor, considering the short exposure time.

A single specimen of Alloy CDA 613 exhibited a corrosion rate of $0.77 \mathrm{~mm}$ per year, the smallest corrosion rates of all alloys tested. Although replicate specimens of this alloy were not tested, the weight-loss result is consistent with the superior corrosion performance of the CDA 613 U-bend specimen versus the CDA 102 U-bend.

Two specimens of Alloy CDA 715 had corrosion rates of 2.32 and $2.34 \mathrm{~mm}$ per year, respectively. The resistance to general corrosion for alloy CDA 715 is found to be between those of Alloy CDA 613 and Alloy 825 and its performance is closer to the performance of Alloy 825. The high corrosion rate of this material in the Paraiki hot spring environment would not be considered satisfactory. The material performance is that of a freely corroding specimen.

\section{Conclusions}

The corrosion performance of Alloy CDA 613 is superior to that of the other alloys tested in the geothermal spring environment at Lake Rotokawa, Paraiki Site Number 9 . However, the $0.77-\mathrm{mm} /$ year corrosion rate is still significant, and is not trivial. The corrosion attack on Alloy CDA 613, which was masked under the fine, granular corrosion product, produced a rather smooth specimen surface, much like it was before the exposure. The fine corrosion product is consistent with the extremely small grain size predominant in the grain structure. There is little evidence of severe degradation of the 
surface as was present in all the other alloys. The worst of the attack appears to be some minor pitting on the U-bend sample and mottled staining of the crevice and weight loss coupons. Longer exposure may well have produced a declining corrosion rate, and for this reason, a second set of tests should be conducted with extended exposure times in order to determine the corrosion rate as a function of time. Since the mode of attack is driven by general corrosion, there is no need to test crevice or U-bend specimens in the future.

Alloys 825 and CDA 715 performed so poorly that further testing of these alloys, in the present metallurgical condition, is not warranted in this environment. Results from weight loss determinations for Alloys 825 and CDA 715 indicated accelerated corrosion rates. The surfaces of both alloys were severely attacked, and the result was permanent alteration, causing them to appear much different from the initial surfaces. The similar grain structures of these two materials may have been a factor in producing the similar attack. Both alloys appear to have a longitudinal cold-worked grain structure that may have provided the impetus for exfoliation-type attack. The resulting surfaces are attacked to such an extent that significant differences in depth of attack occurred across the width of a $25-\mathrm{mm}$ sample. The integrity of the materials is questionable after only six weeks of exposure.

Samples of Type 304L stainless steel and carbon steel dissolved before the end of the six week exposure period. The performance of these alloys is so poor that further testing in this environment is certainly not warranted. 


\section{References}

1. W. Bourcier, Status of Lake Rotokawa Sample Corrosion Tests, internal memorandum, Lawrence Livermore National Laboratory (June 20, 1994).

2. A. E. Ogard and J. F. Kerrisk, Groundwater Chemistry along Flow Path Between aProposed Repository Site and the Accessible Environment, LA-1088-MS, Los Alamos National Laboratory, Los Alamos, NM (1984).

3. M. G. Fontana and N. D. Greene, Corrosion Engineering, McGraw-Hill, Inc., New York, NY (1978), p 43.

4. S. W. Borenstein, Microbiologically influenced corrosion handbook, Industrial Press, Inc., New York, NY (1994), p 23.

5. R. D. McCright, "Updated Candidate List for Engineered Barrier Materials," UCRLID-1 19442, Lawrence Livermore National Laboratory, Livermore, CA (1994).

6. Standard G46-90, Standard Practice for Immersion Testing of U-Bend Corrosion Test Specimens, Annual Book of ASTM Standards, Vol. 3.02, American Society for Testing and Materials, Philadelphia, PA (1990).

7. B. Christenson, telephone communication, Institute of Geological and Nuclear Sciences, New Zealand (November 1, 1994).

8. Standard G1-90, Standard Practice for Preparing, Cleaning, and Evaluating Corrosion Test Specimens, Annual Book of ASTM Standards, Vol. 3.02, American Society for Testing and Materials, Philadelphia, PA. (1990). 


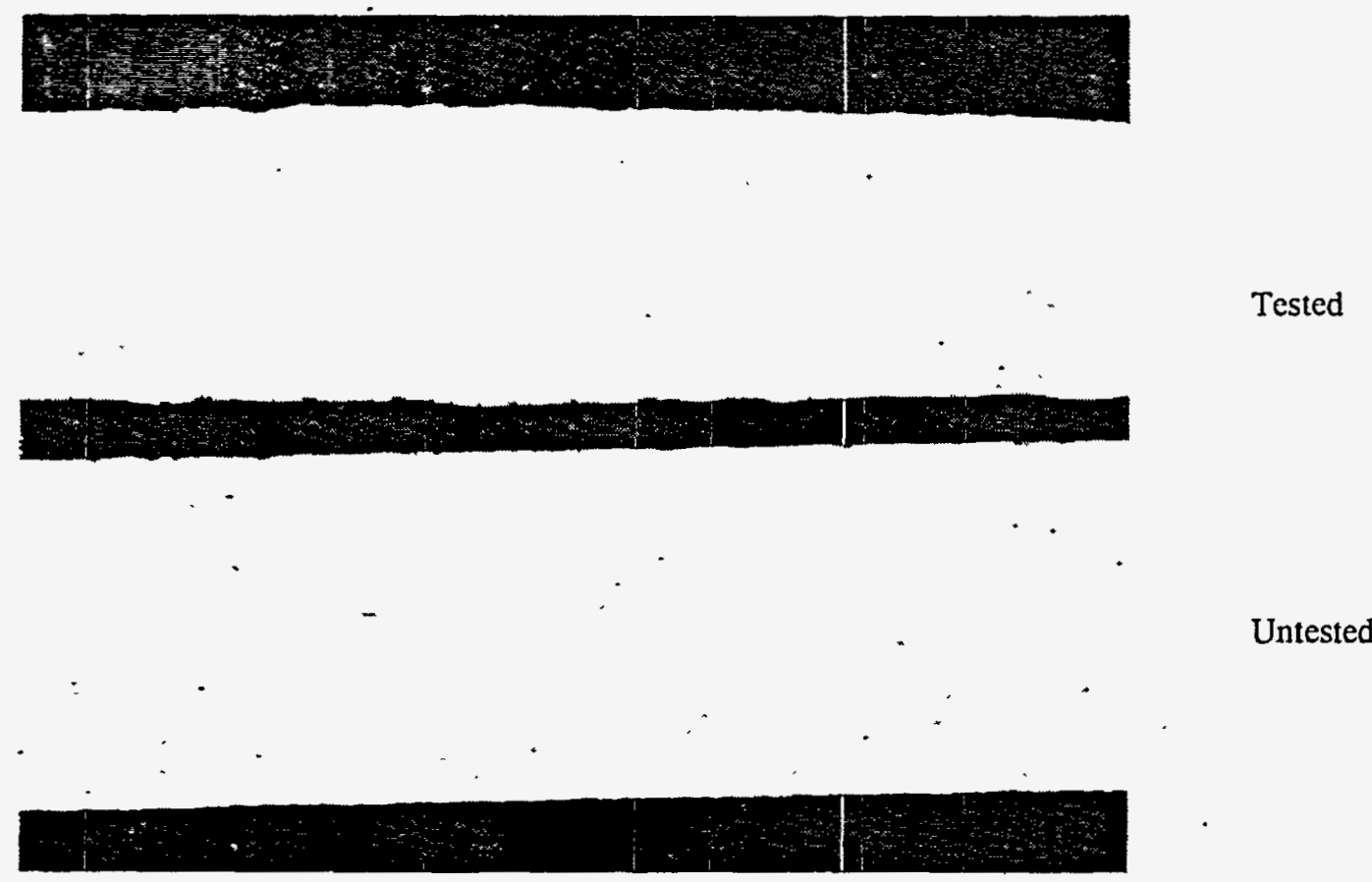

Figure 1. After cleaning. As-polished CDA 613 exposed to Paraiki hot spring for six weeks. 15X
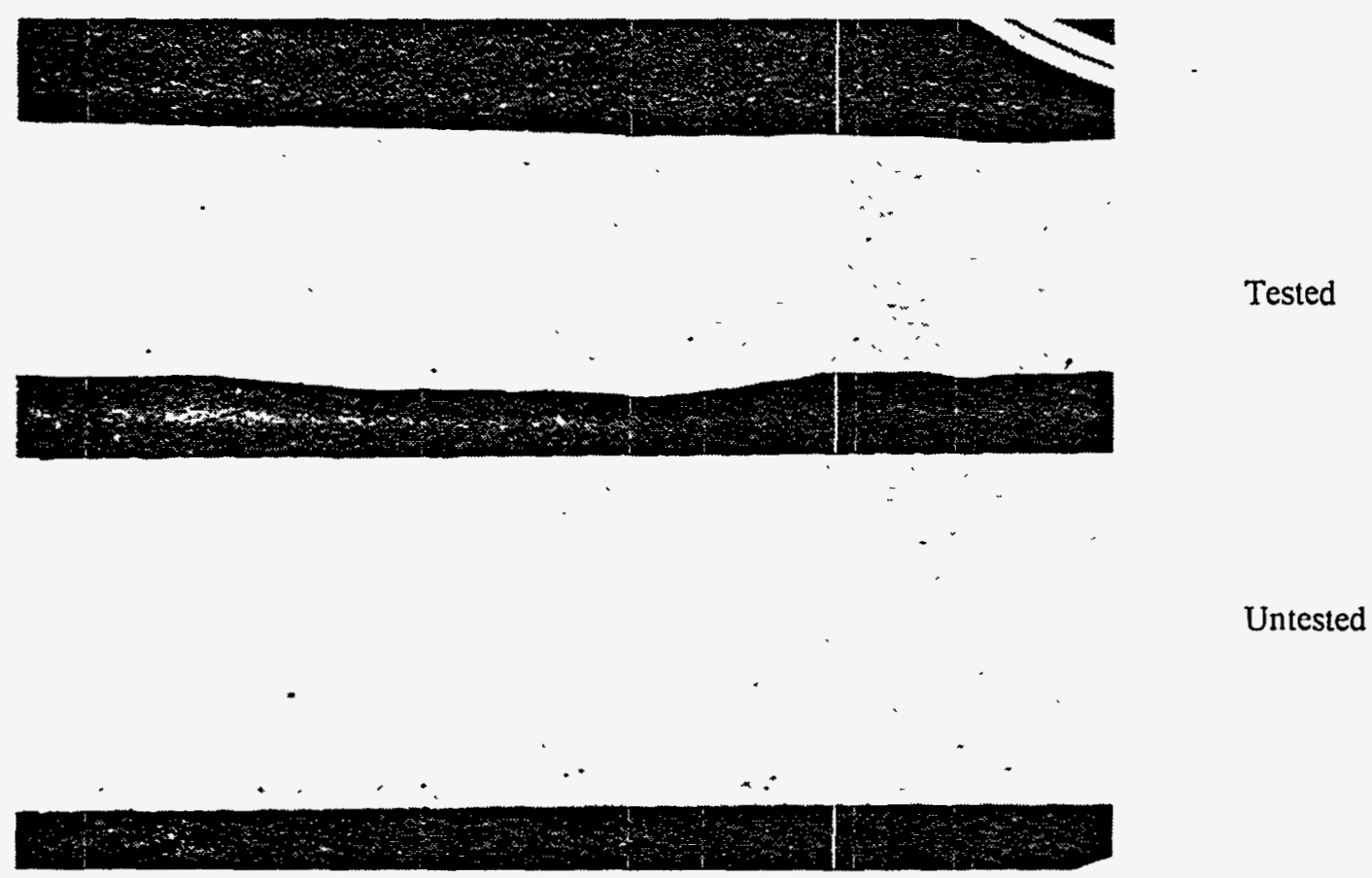

Figure 2. After cleaning. As-polished CDA 715 exposed to Paraiki hot spring for six weeks. 15X 


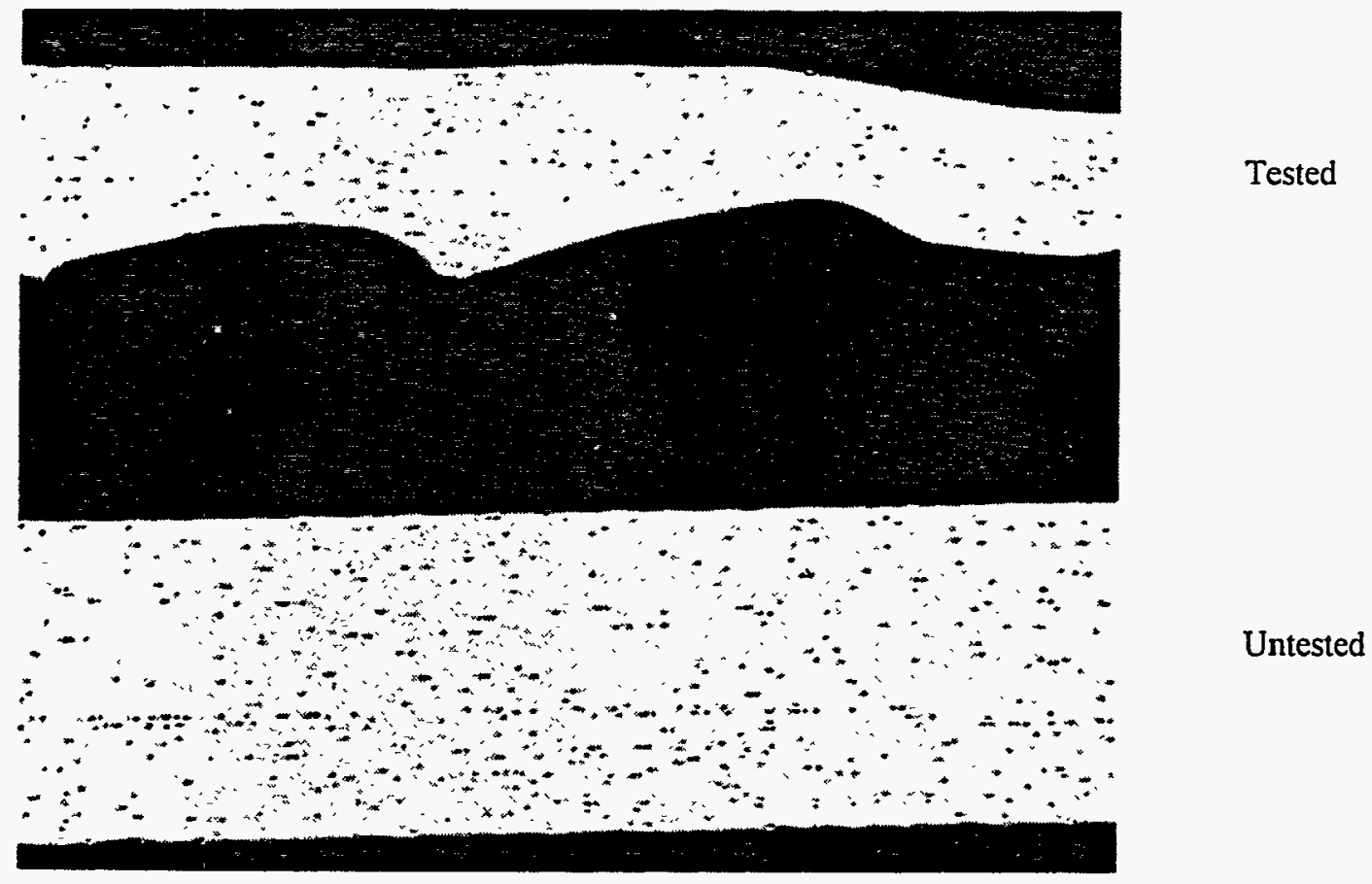

Figure 3. After cleaning. As-polishied Alloy 825 exposed to Paraiki hot spring for six weeks. $15 \mathrm{X}$

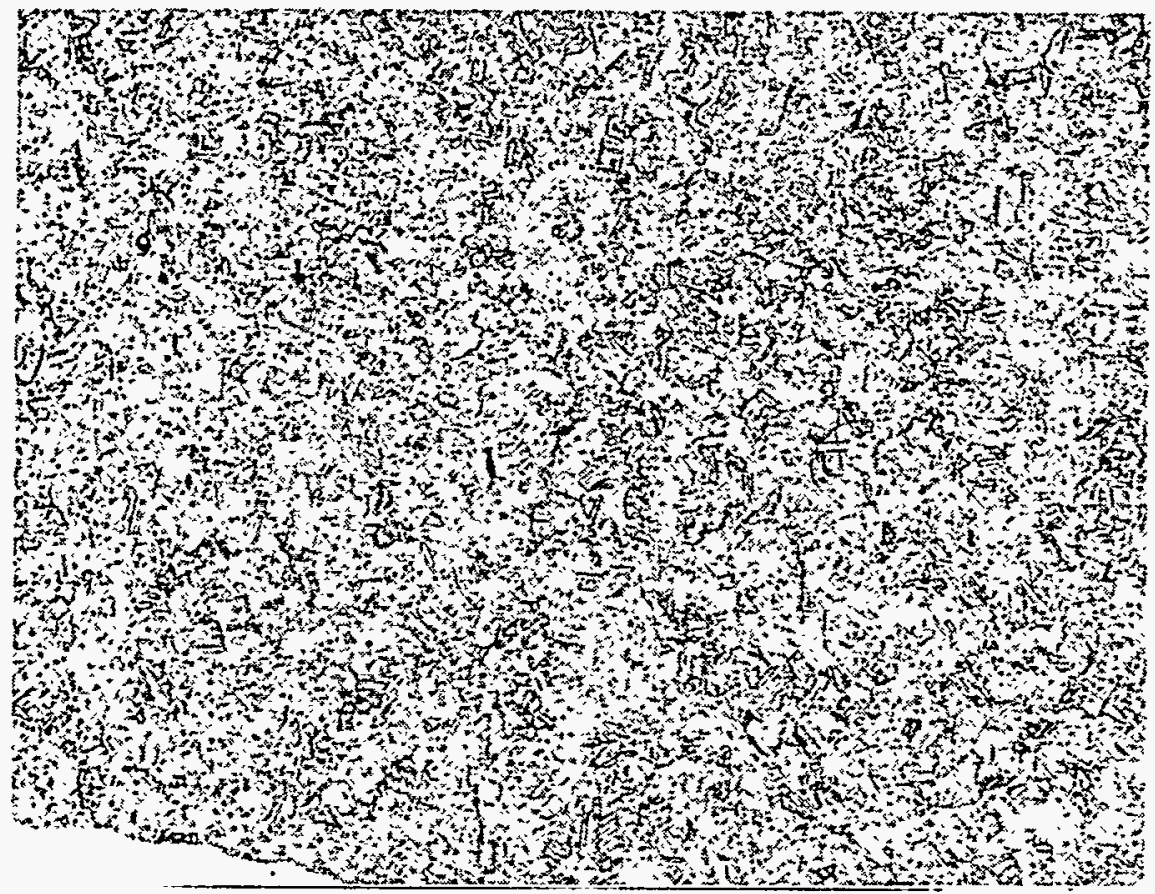

Figure 4. Etched CDA 613 exposed to Paraiki hot spring for six weeks. 500x 


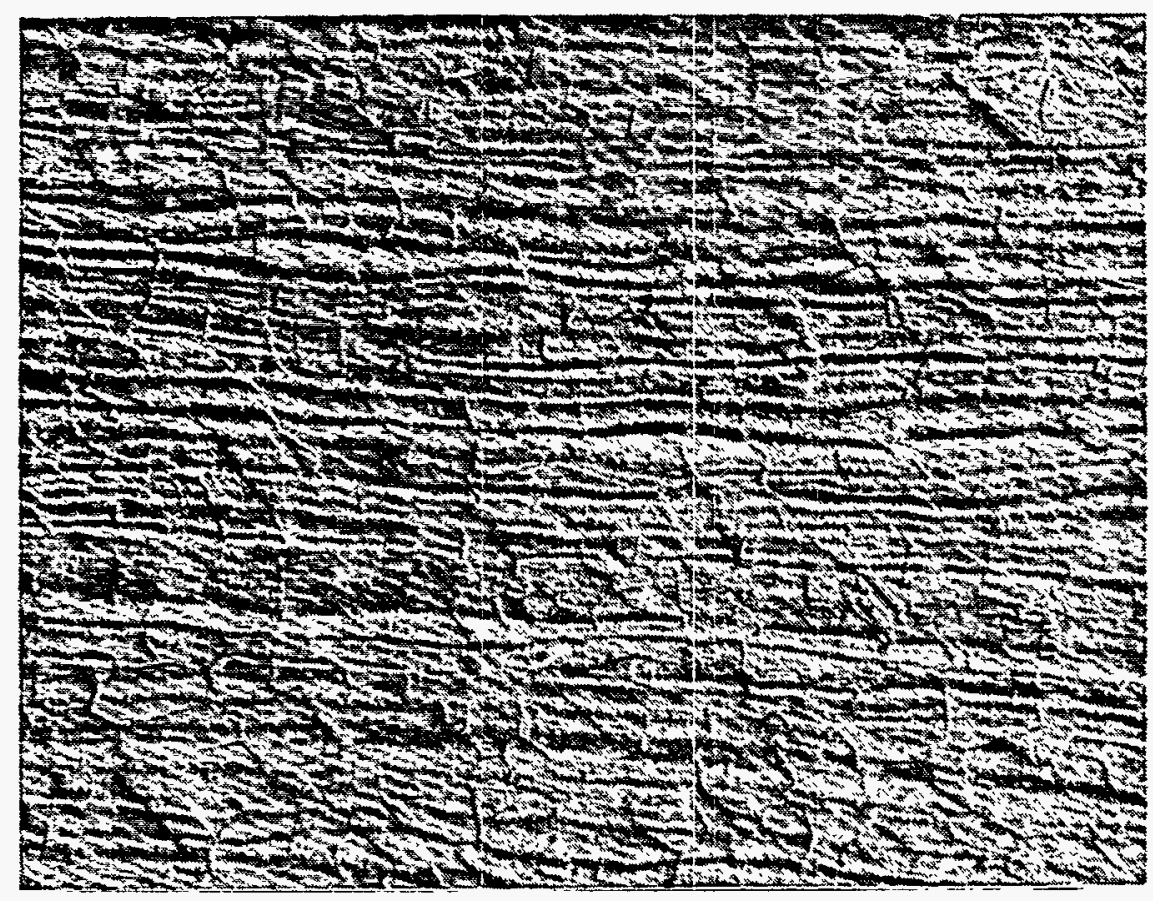

Figure 5. Etched CDA 715 exposed to Paraiki hot spring for six weeks. 500x

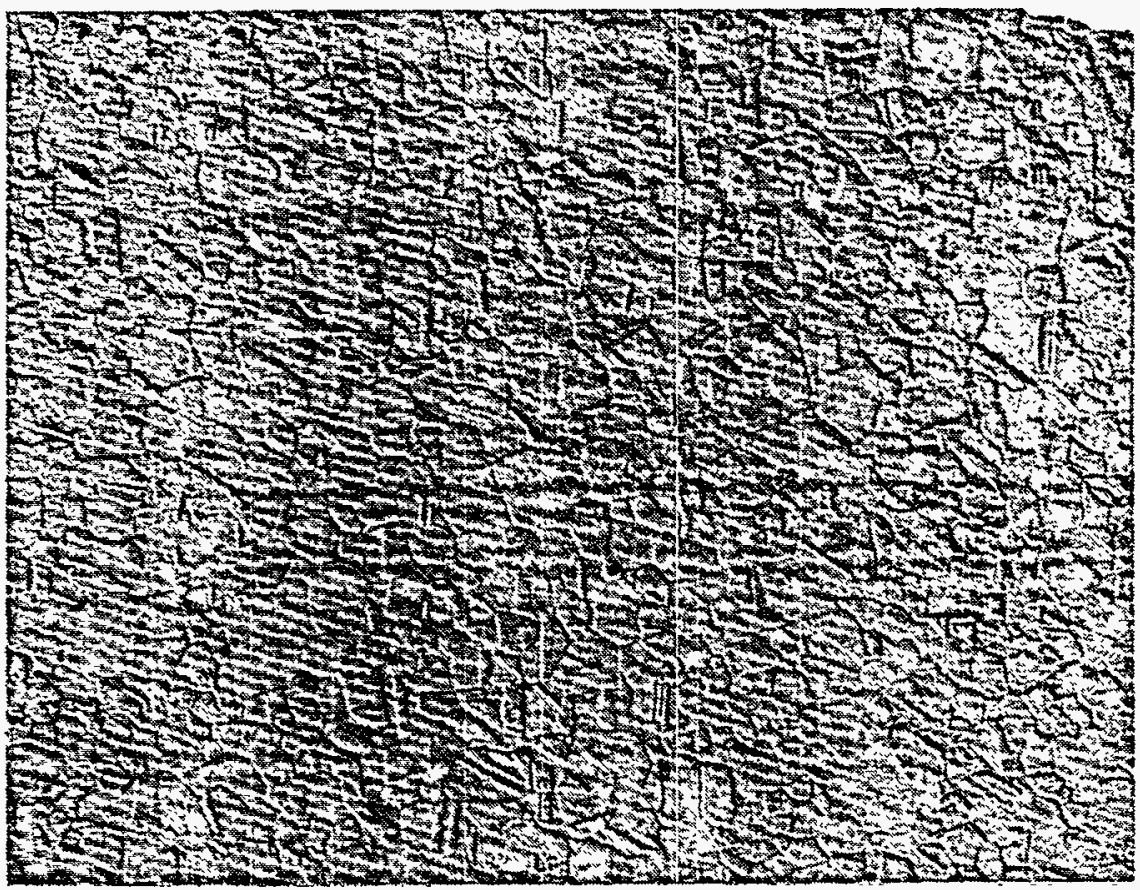

Figure 6. Etched Alloy 825 exposed to Paraiki hot spring for six weeks. 500x 


\begin{tabular}{|c|c|c|c|}
\hline Alloy & Identification & Specimen Type & Description of Corrosion Attack \\
\hline Alloy 825 & 1-825S 262 & 25-mm x 50-mm Flat Weight Loss & $\begin{array}{l}\text { Severe corrosion attack;appears to be exfoliation-type attack with substantial depth. } \\
\text { Failty uniform attack. }\end{array}$ \\
\hline Alloy 825 & $1-8255263$ & 25-mm $\times$ 50-mm Flat Weight Loss & $\begin{array}{l}\text { Severe corrosion attack;appears to be exfoliation-type attack with substantial depth. } \\
\text { Fality uniform attack. }\end{array}$ \\
\hline Alloy 825 & $1-825 S 266$ & 25-mm $\times$ 50-mm Flat Weight Loss & $\begin{array}{l}\text { Most severe corrosion attack with only remnants of exfoliation-type attack, much of the exfoliated surface } \\
\text { dissolved away. Fairly uniform attack. }\end{array}$ \\
\hline CDA 613 & CDA 613-19 & 25-mm x 50-mm Flat Weight Loss & Very fine, granular type corrosion product with significant amount of corrosion product. Uniform attack. \\
\hline CDA613 & CDA $61346-22$ & U.Bend & $\begin{array}{l}\text { Very fine, granular type corrosion product with significant amount of corrosion product. } \\
\text { Uniform attack. No evidence of SCC. Minor pitting attack and dark staining on } 316 \text { SS loading bolt. }\end{array}$ \\
\hline CDA613 & $\begin{array}{l}\operatorname{CDA} 61319 / \\
\operatorname{CDA} 61320\end{array}$ & $\begin{array}{l}\text { Dual specimen; bolted } \\
50-\mathrm{mm} \times 50-\mathrm{mm} \text { Crevice }\end{array}$ & $\begin{array}{l}\text { Very fine, granular type corrosion product with significant amount of corrosion product; very } \\
\text { uniform attack. No crevice corrosion observed. } 316 \text { stainless assembly bolts severely corroded. }\end{array}$ \\
\hline CDA 715 & CDA 715-35 & 25-mm $\times$ 50-mm Flat Weight Loss & $\begin{array}{l}\text { Mixed corrosion product. Both granular and flaky, exfoliation-type corrosion. Substantial depth } \\
\text { of attack at exfoliated areas, somewhat less at granular areas. }\end{array}$ \\
\hline CDA 715 & CDA 715-34 & 25-mm $\times$ 50-mm Flat Welght Loss & $\begin{array}{l}\text { Mixed corrosion product. Both granular and flaky, exfoliation-type corrosion. } \\
\text { Substantial depth of attack at exfoliated areas, somewhat less at granular areas. }\end{array}$ \\
\hline CDA 102 & CDA 102 46-24 & U.Bend & $\begin{array}{l}\text { Very fine, granular corrosion product with significant amount of corrosion product. Very uniform attack. } \\
\text { No evidence of SCC on U-bend. No significant attack on isolated } 316 \mathrm{SS} \text { loading bolt. }\end{array}$ \\
\hline $304 \mathrm{~L}$ & $304 L 46-8$ & U-Bend & Sample dissolved. Nothing to examine. \\
\hline A-36 Steel & A-36 622 & 25-mm x 50-mm Flat Weight Loss & Sample dissolved. Nothing to examine. \\
\hline $\begin{array}{l}1020 \text { Steel } \\
1020 \text { Steel } \\
1020 \text { Steel } \\
1020 \text { Steel }\end{array}$ & $\begin{array}{l}1020740 \\
1020743 \\
1020744 \\
102074-(1)\end{array}$ & $\begin{array}{l}25-\mathrm{mm} \times 50-\mathrm{mm} \text { Flat Weight Loss } \\
25-\mathrm{mm} \times 50-\mathrm{mm} \text { Flat Weight Loss } \\
25-\mathrm{mm} \times 50-\mathrm{mm} \text { Flat Weight Loss } \\
25-\mathrm{mm} \times 50-\mathrm{mm} \text { Flat Weight Loss }\end{array}$ & $\begin{array}{l}\text { Sample dissolved. Nothing to examine. } \\
\text { Sample dissolved. Nothing to examine. } \\
\text { Sample dissolved. Nothing to examine. } \\
\text { Sample dissolved. Nothing to examine. }\end{array}$ \\
\hline
\end{tabular}




\begin{tabular}{|c|c|c|c|}
\hline Alloy & Identification & Specimen Type & Description of Corrosion Attack \\
\hline Alloy 825 & $1-825 S 262$ & $25-\mathrm{mm} \times 50-\mathrm{mm}$ Flat Weight Loss & $\begin{array}{l}\text { Combination of black, brown, and silver-colored surface. Very rough surface with } \\
\text { varying degrees of depth of attack. }\end{array}$ \\
\hline Alloy 825 & $1-825 S 263$ & 25-mm $\times$ 50-mm Flat Weight Loss & $\begin{array}{l}\text { Combination of black, brown, and silver-colored surface; mostly silver. Very rough } \\
\text { surface with varying degrees of depth of attack. }\end{array}$ \\
\hline Alloy 825 & $1-825 S 266$ & 25-mm $\times$ 50-mm Flat Weight Loss & $\begin{array}{l}\text { Shiny, silver color, relattvely clean surface with few spotted areas of deep pits. Overall surface characteristic } \\
\text { is not fiat but rather wavy, probably some undermining degradation below the outer surface layer. }\end{array}$ \\
\hline CDA 613 & $\operatorname{CDA} 613.19$ & 25-mm $\times$ 50-mm Flat Weight Loss & $\begin{array}{l}\text { Fairly clean, smooth surface with little or no pitting. Color same as starting color, yellow bronze. } \\
\text { Mottled stain appearance. No depth of attack observed in the cleaned condition. }\end{array}$ \\
\hline CDA 613 & $\operatorname{CDA} 61346-22$ & U-Bend & $\begin{array}{l}\text { Fairly clean surface, a little rough with uniform attack. Color same as starting color, yellow bronze. Mottled stain appearance. } \\
\text { No depth of attack observed in the cleaned condition. No SCC observed but one nut on loading assembly is pitted. }\end{array}$ \\
\hline $\operatorname{CDA613}$ & $\begin{array}{l}\text { CDA } 61319 / \\
\text { CDA } 61320\end{array}$ & $\begin{array}{l}\text { Dual Specimen; Bolted } \\
50-\mathrm{mm} \times 50-\mathrm{mm} \text { Crevice }\end{array}$ & $\begin{array}{l}\text { Fairly clean, smooth surface with some pitting near the four bolt locations. Color same as starting color, yellow } \\
\text { bronze. Mottled stain appearance. No depth of attack observed in the cleaned condition. }\end{array}$ \\
\hline $\operatorname{CDA} 715$ & CDA $715-35$ & $25 \cdot \mathrm{mm} \times 50 \cdot \mathrm{mm}$ Flat Weight Loss & $\begin{array}{l}\text { Appears to be erosion-corrosion attack. Sample almost appears to be melted, with flowing metal on surface. } \\
\text { Mottled staining of surface. Fairly rough surface with varying degrees of depth of attack. Silvery surface color. }\end{array}$ \\
\hline CDA 715 & CDA 715-34 & 25-mm $\times$ 50-mm Flat Weight Loss & $\begin{array}{l}\text { Appears to be erosion-corrosion attack. Sample almost appears to be melted, with flowing metal on surface. } \\
\text { Mottled staining of surface. Fairly rough surface with varying degrees of depth of attack. Silvery surface color. }\end{array}$ \\
\hline CDA 102 & $\operatorname{CDA} 10246-24$ & U-Bend & $\begin{array}{l}\text { Fairly clean surface, light uniform pitting attack. Color is oxidized copper. Mottled stain appearance. No } \\
\text { depth of attack observed in the cleaned condition. No SCC observed. No corrosion on } 316 \text { SS load bolt assembly. }\end{array}$ \\
\hline $304 \mathrm{~L}$ & $304 \mathrm{~L} 46-8$ & U-Bend & Sample dissolved. Nothing to examine. \\
\hline A-36 Steel & A-36 622 & 25-mm $\times$ 50-mm Flat Weight Loss & Sample dissolved. Nothing to examine. \\
\hline $\begin{array}{l}1020 \text { Steel } \\
1020 \text { Steel } \\
1020 \text { Steel }\end{array}$ & $\begin{array}{l}1020740 \\
1020743 \\
1020744\end{array}$ & $\begin{array}{l}25-\mathrm{mm} \times 50-\mathrm{mm} \text { Flat Weight Loss } \\
25-\mathrm{mm} \times 50-\mathrm{mm} \text { Flat Weight Loss } \\
25-\mathrm{mm} \times 50-\mathrm{mm} \text { Flat Weight Loss }\end{array}$ & $\begin{array}{l}\text { Sample dissolved. Nothing to examine. } \\
\text { Sample dissolved. Nothing to examine. } \\
\text { Sample dissolved. Nothing to examine. }\end{array}$ \\
\hline 1020 Steel & $102074-(1)$ & $25-\mathrm{mm} \times 50-\mathrm{mm}$ Flat Weight Loss & Sample dissolved. Nothing to examine. \\
\hline
\end{tabular}


Table 4. Corrosion Rates of Alloys Exposed to Pairiki Site 9 at Lake Rotokawa, New Zealand

\begin{tabular}{|c|c|c|c|c|c|c|c|c|c|c|c|c|}
\hline Alloy & Identification & Length & Width & Thickness & $\begin{array}{r}\text { Mounting } \\
\text { Hole } \\
\text { Diameter } \\
\mathrm{cm}\end{array}$ & $\begin{array}{l}\text { Welght } \\
\text { Inttial }\end{array}$ & $\begin{array}{l}\text { Welght } \\
\text { Final }\end{array}$ & $\begin{array}{l}\text { Welght } \\
\text { Loss }\end{array}$ & $\begin{array}{r}\text { Exposure } \\
\text { Duration } \\
\\
\mathbf{h r}\end{array}$ & $\begin{array}{r}\text { Surface } \\
\text { Area } \\
\\
s q \mathrm{~cm}\end{array}$ & $\begin{array}{l}\text { Density } \\
\mathrm{g} / \mathrm{cm}^{3}\end{array}$ & $\begin{array}{r}\begin{array}{r}\text { Corroslon } \\
\text { Rate }\end{array} \\
\mathrm{mm} / \mathrm{y}\end{array}$ \\
\hline $\begin{array}{l}\text { Alloy } 825 \\
\text { Alloy } 825 \\
\text { Alloy } 825\end{array}$ & $\begin{array}{l}1-825 S 266 \\
1-825 S 262 \\
1-825 S 263\end{array}$ & $\begin{array}{l}5.103 \\
5.098 \\
5.090\end{array}$ & $\begin{array}{l}2.578 \\
2.565 \\
2.527\end{array}$ & $\begin{array}{l}0.165 \\
0.191 \\
0.165\end{array}$ & $\begin{array}{l}0.617 \\
0.584 \\
0.632\end{array}$ & $\begin{array}{l}16.2177 \\
16.3297 \\
16.0487\end{array}$ & $\begin{array}{r}4.1642 \\
12.7813 \\
10.7138\end{array}$ & $\begin{array}{r}12.0535 \\
3.5484 \\
5.3349\end{array}$ & $\begin{array}{l}1008 \\
1008 \\
1008\end{array}$ & $\begin{array}{l}28.25 \\
28.54 \\
27.62\end{array}$ & $\begin{array}{l}8.14 \\
8.14 \\
8.14\end{array}$ & $\begin{array}{l}4.56 \\
1.33 \\
2.06\end{array}$ \\
\hline $\begin{array}{l}\text { CDA } 715 \\
\text { CDA 715 }\end{array}$ & $\begin{array}{l}\text { CDA 715-35 } \\
\text { CDA 715-34 }\end{array}$ & $\begin{array}{l}5.121 \\
5.121\end{array}$ & $\begin{array}{l}2.581 \\
2.586\end{array}$ & $\begin{array}{l}0.183 \\
0.188\end{array}$ & $\begin{array}{l}0.620 \\
0.625\end{array}$ & $\begin{array}{l}19.2286 \\
19.8294\end{array}$ & $\begin{array}{l}12.3342 \\
12.9733\end{array}$ & $\begin{array}{l}6.8944 \\
6.8561\end{array}$ & $\begin{array}{l}1008 \\
1008\end{array}$ & $\begin{array}{l}28.64 \\
28.77\end{array}$ & $\begin{array}{l}8.94 \\
8.94\end{array}$ & $\begin{array}{l}2.34 \\
2.32\end{array}$ \\
\hline $\begin{array}{l}1020 \text { Steel } \\
1020 \text { Steel } \\
1020 \text { Steel } \\
1020 \text { Steel }\end{array}$ & $\begin{array}{l}1020740(1) \\
1020743(1) \\
1020744(1) \\
102074-^{*}(1)\end{array}$ & $\begin{array}{r}5.093 \\
5.093 \\
5.093 \\
\text { Unknown }\end{array}$ & $\begin{array}{r}2.563 \\
2.588 \\
2.553 \\
\text { Unknown }\end{array}$ & $\begin{array}{r}0.201 \\
0.191 \\
0.196 \\
\text { Unknown }\end{array}$ & $\begin{array}{r}0.620 \\
0.627 \\
0.615 \\
\text { Unknown }\end{array}$ & $\begin{array}{r}17.1542 \\
17.2003 \\
17.0959 \\
\text { Unknown }\end{array}$ & $\begin{array}{l}0 \\
0 \\
0 \\
0\end{array}$ & $\begin{array}{r}17.1542 \\
17.2003 \\
17.0959 \\
\text { Unknown }\end{array}$ & $\begin{array}{l}1008 \\
1008 \\
1008 \\
1008\end{array}$ & $\begin{array}{r}28.57 \\
28.67 \\
28.40 \\
\text { Unknown }\end{array}$ & $\begin{array}{l}7.87 \\
7.87 \\
7.87 \\
7.87\end{array}$ & $\begin{array}{r}6.63 \\
6.62 \\
6.65 \\
\text { Unknown }\end{array}$ \\
\hline
\end{tabular}

(1)-Sample dissolved and was not on the wire when removed from hot spring. Corrosion rates are minimum values due to unknown time-to-complete dissolution.
- Sample Identification reported as 102074 ; last digit missing. Unknown specimen identification and therefore many parameters are unknown

